\title{
Răspunderea persoanei juridice pentru infracțiuni contra patrimoniului
}

\author{
Lector univ. dr. Andra-Roxana Trandafir \\ Facultatea de Drept, Universitatea din București
}

\begin{abstract}
Rezumat: Materialul prezintă datele statistice în materia răspunderii penale a persoanei juridice pentru infracțiunile contra patrimoniului. Analiza acestor date arată că, deși există un număr destul de mare de persoane juridice cercetate pentru astfel de infracțiuni, procentul celor trimise în judecată este mic. Majoritatea persoanelor juridice care ajung în fața instanțelor sunt cercetate pentru infracțiunea de înșelăciune, dar alte infracțiuni sunt de asemenea prezente.
\end{abstract}

Cuvinte cheie: persoane juridice, date statistice, înșelăciune, furt, abuz de încredere

\section{Criminal liability of legal persons for crimes against property}

Abstract: The paper presents the statistical data in the field of criminal liability of legal persons for offences against property. The analysis of these data shows that, althought many legal persons are investigated for such criminal offences, the percetange of the ones sent in front of the court is actually low. The majority of the legal persons who are being judged perpetrated a type of fraud, but other criminal offences are also encountered.

Key words: legal persons, statistical data, fraud, theft, breach of trust

La o analiză a datelor statistice conținute în Rapoartele de activitate ale Ministerului Public ${ }^{1}$, rezultă că, anual, există un procent mai mare (38\%) sau mai mic (4\%) de infracțiuni contra patrimoniului pentru care persoanele juridice au fost trimise în judecată în perioada 2009-2019. Situația persoanelor juridice cercetate pentru astfel de infracțiuni este însă diferită: au fost 1362 persoane juridice cercetate în perioada 2007-2019, dintre care 192 au fost trimise în judecată prin rechizitoriu și una prin acord de recunoaștere a vinovăției. Se remarcă aşadar, în această materie, numărul mare de persoane juridice netrimise în judecată (1169), adică un procent de $85.83^{2}$, printre cele mai mari din categoria tuturor infracțiunilor reținute în sarcina acestor entităţi. Situația persoanelor juridice cercetate, pe ani, se regăsește în graficul următor:

\footnotetext{
* Materialul face parte din lucrarea Răspunderea penală a persoanei juridice, ce va apărea la începutul lunii septembrie 2020 la Ed. C.H. Beck.

${ }^{1}$ A se vedea rapoartele existente pe site-ul mpublic.ro.

2 Datele sunt calculate pe baza informațiilor conținute în Adresele nr. 3305 din 23 octombrie 2019 și 981 din 29 aprilie 2019 transmise de Ministerul Public ca răspuns la solicitarea noastră de date statistice privind răspunderea penală a persoanelor juridice.
} 


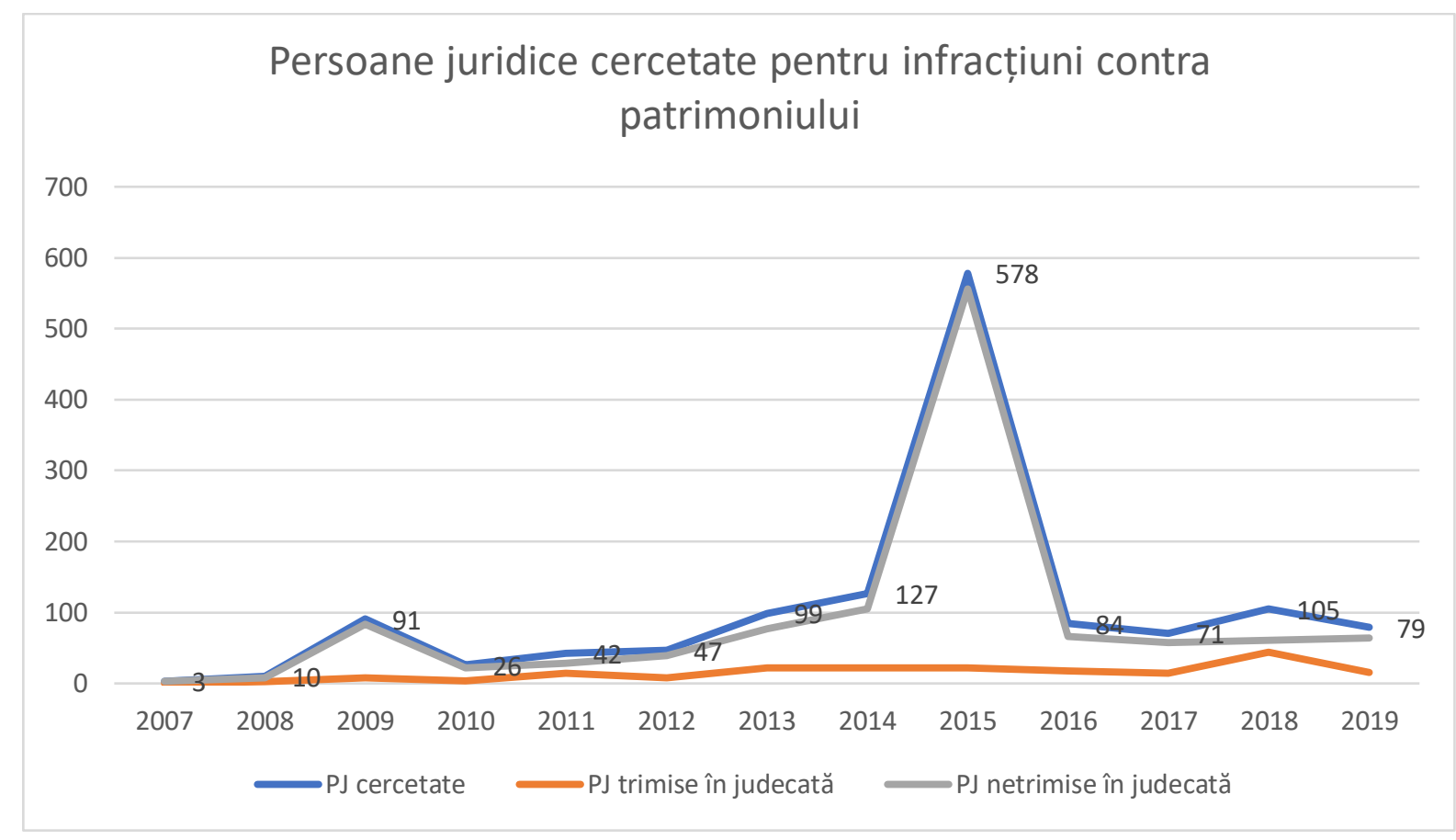

Este evident, așa cum rezultă din aceste date, că infracțiunile contra patrimoniului sunt deseori legate de entitățile colective, chiar dacă ele nu ajung în realitate în faţa instanţelor. Desigur, există anumite infracțiuni ,,vedetă”, pentru care persoanele juridice sunt cu precădere cercetate ori chiar condamnate, în timp ce alte infracțiuni rămân mai degrabă excepții. Le vom analiza pe fiecare în cele ce urmează.

\section{Infracțiuni de furt}

Deși la o primă vedere pare puțin probabil, în practica judiciară s-a pus problema reținerii infracțiunii de furt în sarcina persoanei juridice. 153 de persoane juridice, majoritatea societăți, au fost cercetate pentru această infracțiune în perioada 2007 - 2019, dar numai 21 au fost trimise în judecată (toate prin rechizitoriu) ${ }^{3}$.

De exemplu, într-o cauză, o societate care ca avea ca obiect de activitate recuperarea de obiecte date în leasing a fost trimisă în judecată pentru comiterea infracțiunii de furt calificat, reținându-se în esenţă, în actul de sesizare al instanţei, că, prin intermediul unui angajat al său, care a acționat în realizarea obiectului de activitate şi interesul persoanei juridice, a luat fără drept din posesia legitimă a unei persoane (utilizator potrivit contractului de leasing încheiat cu o instituție financiară nebancară) plăcutele de înmatriculare ale autoturismului, proprietatea societății, pentru a le remite acesteia din urmă. Atât prima instanță, cât și instanța de apel au decis că se impune achitarea societății și a angajatului care a luat plăcuțele de înmatriculare din posesia utilizatorului, întrucât lipsește scopul însușirii pe nedrept specific infracțiunii de furt, ceea ce rezultă din aceea ,că inculpatul H.G. nu şi-a însuşit cele două plăcuţe de înmatriculare în scopul de a intra în posesia acestora şi de a beneficia de bunul sustras, ci în scopul realizării obiectului de activitate al societăţii la care era angajat în acel moment, respectiv S.C. A.R. $S R L " 4$. Așa cum am arătat și cu altă ocazie, deşi pe fondul cauzei, achitarea inculpatului

\footnotetext{
${ }^{4}$ A se vedea Jud. Cluj-Napoca, secţia penală, sentința penală nr. 1512 din 22 decembrie 2011, definitivă prin respingerea recursului de către C.A. Cluj, secţia penală şi de minori, prin decizia nr. 726/R/2 din 10 mai 2012, cu
} 
persoană fizică şi a persoanei juridice pentru săvârşirea infracţiunii de furt apare ca judicioasă, câteva precizări trebuie făcute cu privire la existenţa infracţiunii de furt. Subliniem că nu se poate afirma cu titlu general că însuşirea plăcuţelor de înmatriculare ale unui autoturism de către un angajat al unei societăţi de recuperare a bunurilor date în leasing, din cauza neplăţii ratelor de leasing, ,nu întruneşte elementele constitutive ale infracţiunii de furt, întrucât lipseşte scopul însuşirii pe nedrept, fapta fiind comisă în baza mandatului primit de la persoana juridică, însă cu depăşirea limitelor acestuia", întrucât o asemenea interpretare ar echivala cu o încurajare dată unor astfel de persoane să acţioneze în afara limitelor legale şi contractuale aplicabile în această materie. Apreciem că instanţa de fond ar fi trebuit să analizeze mai temeinic dacă bunul a fost luat în scopul însuşirii pe nedrept, deoarece nu ori de câte ori există o depăşire a limitelor mandatului, înseamnă că lipseşte şi scopul prevăzut de lege pentru existenţa infracţiunii de furt. Însușirea presupune trecerea bunului din sfera de stăpânire a subiectului pasiv și trecerea lui în sfera de stăpânire a subiectului activ ${ }^{5}$, fiind fără relevanță dacă făptuitorul a luat bunul pentru sine sau pentru altul ori dacă acesta a păstrat bunul. Ceea ce este relevant este că făptuitorul se comportă cu privire la bun ca și cum ar fi al lui. Chiar dacă, într-adevăr, în speţa de faţă, este evident că scopul însușirii pe nedrept lipseşte în ceea ce priveşte persoana juridică, nu la fel de clară este o asemenea absenţă în ceea ce-1 priveşte pe inculpatul persoană fizică ${ }^{6}$.

Există și alte dosare în care s-a ridicat problema răspunderii penale a persoanei juridice pentru furt, instanțele admițând o astfel de posibilitate, fără însă a se ajunge încă la o analiză pe fondul cauzei ${ }^{7}$.

\section{Abuz de încredere}

Infracțiunea de abuz de încredere face parte dintre cele ușor de imaginat în sarcina unei persoane juridice, dat fiind faptul că, de multe ori, aceasta este ceea ce încheie un contract netranslativ de proprietate în temeiul căruia primește un bun. Practica judiciară interpretează însă în mod larg noțiunea de „,persoană căreia i s-a încredințat un bun cu un anumit titlu și intr-un anumit scop". Astfel, într-o cauză în care o societate a încheiat un contract de leasing, în calitate de utilizator, având ca obiect dreptul de folosinţă a unui echipament buldoexcavator, fără ca ulterior să plătească ratele corespunzătoare la termenele convenite şi nici să restituie bunul ca urmare a notificării în acest sens primite de la proprietar, instanța a reținut infracțiunea de abuz de încredere în sarcina administratorului societăţii utilizatoare. Este interesant de observat că persoana fizică a încercat să se apere arătând că societatea ,este cea care ar trebui să răspundă penal şi nu inculpatul ca persoană fizică, întrucât contractul a fost încheiat cu această societate”. Instanța a reținut însă că se reţine că apărarea este vădit neîntemeiată, având în vedere, pe de o parte, că societatea ca persoană juridică a fost reprezentată de administratorul său și, pe de altă parte, că dispoziţiile art. $19^{1}$ C.pen. din 1969, reiterate în art. 135 alin. (1) şi (3) C.pen. prevăd că persoanele juridice răspund penal pentru infracţiunile săvârşite în realizarea obiectului de activitate sau în interesul ori în numele persoanei juridice, dacă fapta a fost săvârşită cu forma de vinovăţie prevăzută de legea penală, iar răspunderea penală a

notă de A.R. Trandafir (Ilie), Răspunderea penală a persoanei juridice. Jurisprudență rezumată și comentată, Ed. C.H. Beck, București, 2013, p. 209 și urm.

${ }^{5}$ A se vedea V. Cioclei, Drept penal. Partea specială I. Infracțiuni contra persoanei și infracțiuni contra patrimoniului, ed. a 4-a, Ed. C.H. Beck, București, 2019, p. 246.

${ }^{6}$ A se vedea Nota la Jud. Cluj-Napoca, secţia penală, sentința penală nr. 1512 din 22 decembrie 2011, disponibilă la adresa www.rolii.ro.

${ }^{7}$ A se vedea, de exemplu, Jud. Târgu-Bujor, secția penală, sentința penală nr 72 din 3 aprilie 2013; Jud. TârguBujor, secția penală, sentința penală nr. 332 din 24 aprilie 2013, ambele disponibile la adresa www.rolii.ro. 
persoanei juridice nu exclude răspunderea penală a persoanei fizice care a contribuit, în orice mod, la săvârşirea aceleiaşi infracţiuni ${ }^{8}$. Într-adevăr, dispoziţiile legale privind cumulul răspunderii persoanei fizice cu cea a persoanei juridice nu lasă urmă de interpretare. Ar fi fost însă binevenită o analiză a instanței cu privire la deținerea bunului de către persoana fizică, având în vedere că, într-adevăr, contractul de leasing era încheiat cu societatea, iar nu cu administratorul său. Deși s-ar putea ajunge la o soluție similară (cea a condamnării persoanei fizice, dar alături de persoana juridică), credem că ar fi fost nevoie de o motivare mai precisă (de exemplu, s-ar putea imagina o motivare care să arate că, în temeiul contractului de leasing, folosința bunului se transmite nu doar către persoana juridică, dar și către persoanele care, potrivit regulilor interne, au dreptul să decidă asupra respectivului bun - deși, din punct de vedere civil, acestea dețin bunul în temeiul altui titlu, care provine de la angajatorul lor, precum un contract de mandat sau de muncă - și că nu se poate admite o perspectivă care să limiteze subiectul activ al abuzului de încredere la partea din contract, întrucât astfel s-ar eluda ușor dispozițiile legii penale privind răspunderea persoanei fizice, persoana juridică nefiind decât un „paravan” pentru comiterea de fapte penale; în orice caz, și dacă am interpreta textul de lege restrictiv, persoana fizică tot ar putea răspunde, în calitate de complice la respectiva infracțiune etc.).

\section{Bancrută frauduloasă}

Nouă persoane juridice au fost cercetate penal pentru infracțiunea de bancrută frauduloasă, iar trei au fost trimise în judecată în perioada $2007-2019^{9}$.

Într-unul din aceste dosare, confruntată cu posibilitatea ca o persoană juridică să comită infracțiunea de bancrută frauduloasă, instanța supremă a decis că, în procedura insolvenţei, fapta reprezentantului administratorului judiciar care, în frauda creditorilor, înscrie în tabelul de creanţe o creanţă sub condiţie suspensivă ca fiind o creanţă pură şi simplă, deşi condiţia nu este îndeplinită şi, prin urmare, suma care reprezintă valoarea creanţei nu este datorată - cu consecinţa efectuării plăţii acestei sume nedatorate, întruneşte elementele constitutive ale infracţiunii de bancrută frauduloasă prevăzută în vechile dispoziţii ale art. 143 alin. (2) lit. b) din Legea nr. 85/2006, care au corespondent în art. 241 alin. (1) lit. b) C.pen., ce incriminează fapta persoanei care, în frauda creditorilor, înfăţişează datorii inexistente sau prezintă în registrele debitorului, în alt act sau în situaţia financiară sume nedatorate, iar societatea profesională cu răspundere limitată, ca formă de exercitare a profesiei de practician în insolvenţă cu personalitate juridică, desemnată administrator judiciar în procedura insolvenţei, răspunde penal pentru infracţiunea de bancrută frauduloasă săvârşită de reprezentantul său, în realizarea obiectului de activitate al societăţii desemnate administrator judiciar în procedura insolvenţei ${ }^{10}$.

\section{4. Înșelăciune}

Dintre infracțiunile contra patrimoniului, infracțiunea de înșelăciune este cel mai des reținută în sarcina persoanelor juridice. Totodată, din rândul infracțiunilor prevăzute în Codul penal,

\footnotetext{
${ }^{8}$ A se vedea C.A. Bacău, secția penală, cauze minori și familie, decizia nr. 1059 din 12 octombrie 2016, definitivă, disponibilă la adresa www.rolii.ro. În același sens, a se vedea Jud. Constanța, secția penală, sentința penală nr. 558 din 27 aprilie 2015, disponibilă la adresa www.rolii.ro.

${ }^{9}$ Adresa 3305 şi Adresa 981, cit. supra.

${ }^{10}$ A se vedea I.C.C.J., secţia penală, decizia nr. 248/A din 2 iulie 2015, disponibilă la adresa www.scj.ro. Pentru analiza reținerii infracțiunii de bancrută frauduloasă în sarcina persoanei juridice, a se vedea D. Pârgaru, Infracțiuni în legătură cu procedura insolvenței. Teză de doctorat, Universitatea din București, 2019, p. 157.
} 
este cea pentru care persoanele juridice au fost cel mai adesea cercetate. Astfel, 876 de persoane juridice au fost cercetate în perioada 2007-2019, dintre care (doar) 147 au fost trimise în judecată (una prin acord de recunoaștere a vinovăției și toate celelalte prin rechizitoriu) ${ }^{11}$. Modalitățile faptice de comitere a faptei sunt dintre cele mai variate.

\section{A. Înșelăciune în relațiile între profesioniști prin cecuri sau bilete la ordin}

S-a reținut, de exemplu, infracțiunea de înșelăciune în sarcina unei societăți care a încheiat mai multe contracte de vânzare-cumpărare a unor mărfuri necesare desfăşurării activităţii societăţii, pentru achitarea cărora a emis în favoarea unor alte societăţi 33 de file cec şi 37 de bilete la ordin, fără a avea disponibil necesar în cont şi fără ca societăţile respective să cunoască incapacitatea de plată. Prin această modalitate, s-a reuşit înşselarea unui număr de 14 societăţi comerciale furnizoare, cauzându-le acestora un prejudiciu ${ }^{12}$.

Într-o altă cauză, s-a reținut infracțiunea de înșelăciune în sarcina unei societăți care a indus în eroare reprezentanții unei alte societăţi cu ocazia încheierii unui contract, creând impresia că la acea dată societatea își desfasoară activitatea comercială în mod normal, că avea deschis cont la bancă, precum și faptul că vor achita contravaloarea mărfii ridicate, pentru plata carora au emis un bilet la ordin, refuzat însă la plată din lipsa de disponibil ${ }^{13}$.

\section{B. Înșelăciune prin crearea unei aparențe de bonitate comercială}

S-a reținut, de asemenea, infracțiunea de înșelăciune într-o cauză în care două societăți au creat o serie de circuite de documente în cazul utilajelor de construcţii, pentru a da aparenţa de legalitate a operaţiunilor comerciale derulate, fiind emise facturi care aveau înscrise operaţiuni comerciale nereale. Conform documentelor existente la dosar, una dintre societăți a înregistrat în patrimoniu şi în evidenţele contabile achiziţii în baza unor facturi cu operaţiuni comerciale nereale, iar cealaltă a procedat în acelaşi mod când a înregistrat achiziţionarea acestor utilaje de la societatea cealaltă şi vânzarea mai departe către IFN-uri. Modalitatea de lucru utilizată în aproape toate cazurile analizate de vânzări de utilaje către IFN-uri este următoarea: o societate încheia contractele de vânzare-cumpărare utilaje de construcţii şi emitea facturile către societăţile de leasing, care erau încasate de regulă la diferenţă de câteva zile de la emitere şi după încasarea contravalorii acestor facturi în conturile bancare, se emiteau facturile de aprovizionare, realizându-se circuitul de documente conform celor prezentate. După încasarea banilor proveniţi din înşelarea societăţilor de leasing, se întocmea documentaţia financiar contabile justificative de achiziţie a utilajului ce făcea obiectul contractului, precum şi de transferarea sumelor de bani către conturile altor societăţi comerciale de unde îi extrăgea în numerar. Crearea aparenţei realităţii şi legalităţii operaţiunilor de achiziţionarea şi comercializare a utilajelor de către această societate avea o dublă valenţă: pe de o parte, în cazul unui control pe linie financiar-contabilă, existenţa documentelor justificative de achiziţie (,intrarea”) creau impresia realităţii operaţiunilor iar pe de alta, evidenţierea operaţiunilor în contabilitatea societăţii conducea la creşterea bonităţii acesteia prin crearea aparenţei unei activităţi comerciale remarcabile ${ }^{14}$.

\footnotetext{
${ }^{11}$ Adresa 3305 și Adresa nr. 981.

12 A se vedea Trib. Buzău, secţia penală, sentința penală nr. 123 din 14 iulie 2009, definitivă, cu notă de A.R. Trandafir, Răspunderea penală a persoanei juridice. Jurisprudență rezumată și comentată, cit. supra, p. 221 și urm.

${ }^{13}$ A se vedea Jud. Bacău, sentința penală nr. 668 din 8 aprilie 2013, disponibilă la adresa www.rolii.ro.

${ }^{14}$ A se vedea Trib. Bucureşti, secţia a II-a penală, sentința penală nr. 846 din 6 decembrie 2010, definitivă, cu notă de A.R. Trandafir (Ilie), Răspunderea penală a persoanei juridice. Jurisprudență rezumată și comentată, cit.
} 


\section{C. Înșelăciune prin emiterea de adeverințe de muncă conținând date nereale, în vederea obținerii unui credit de către persoane fizice}

Mai multe dosare penale au ridicat problema participaţiei penale la infracțiunea de înșelăciune în situația în care au fost eliberate adeverințe care atestau calitatea de angajat a unor persoane la o societate unde nu lucraseră niciodată. Astfel, s-a apreciat că reprezintă complicitate la înșelăciune, precum și la uz de fals, fapta unei societăţi al cărei administrator, a semnat la rubrica „reprezentant legal al angajatorului”, în dreptul propriului nume, o adeverinţă ce urma să ateste calitatea de angajat a unei persoane la respectiva societate, deşi nicio persoană nu figura ca angajat acel moment, iar după contrafacerea unui contract individual de muncă, a semnat cu știință pentru conformitate pe copia acestuia, toate aceste acte fiind folosite pentru obţinerea unui credit bancar, inducând în eroare reprezentanţii băncii, prin prezentarea ca adevărată a împrejurării mincinoase că este angajat la respectiva societate ${ }^{15}$. Dimpotrivă, întro cauză similară, la nivelul aceleiași instanțe există practică potrivit cu care persoana juridică trebuie achitată pentru complicitate la înșelăciune, întrucât nu se poate dovedi că fapta a fost comisă în realizarea obiectului de activitate, în numele sau în interesul său, simplul fapt că administratorul a semnat niște adeverințe neînsemnând că vreuna din aceste condiții este îndeplinită ${ }^{16}$. În ceea ce ne privește, apreciem că nu există dubii cu privire la reținerea elementului material în sarcina persoanei juridice, atâta vreme cât adeverința este emisă de societate și poartă ștampila acesteia, însă ar fi trebuit făcută o discuție cu privire la elementul subiectiv propriu persoanei juridice. De altfel, în alte cauze, s-a reținut că față de persoana juridică nu s-a putut stabili o culpă distinctă de cea a angajaţilor săi, astfel încât se impune achitarea acesteia pentru infracțiunea de înșelăciune ${ }^{17}$.

\section{D. Înșelăciune în domeniul medical}

Într-un caz foarte mediatizat, alături de infracțiunile de uz de fals și participație improprie la zădărnicirea combaterii bolilor, s-a reținut că o societate , în intervalul 1 iunie 2010 - 16 mai 2016, a indus în eroare reprezentanții a 340 de unități sanitare prin prezentarea ca adevărată a unor calități mincinoase ale produselor proprii, referitoare la concentrația substanțelor active și la eficiența biocidă, precum și prin utilizarea de mijloace frauduloase constând $\hat{\imath}$ etichete și alte înscrisuri ce atestă elemente de conformitate nereale, determinându-i în acest mod să încheie contracte de achiziție de produse biocide și pricinuindu-le o pagubă" ${ }^{18}$, fapte care întrunesc elementele constitutive ale 310 infracțiuni de înșelăciune în formă continuată,

supra,p. 395 și urm., de asemenea și în Notă la sentinţa nr. 846 din 6 decembrie 2010 pronunţată de Trib. București, secţia a II-a penală, definitivă la 22 mai 2012, AUBD 2013, p. 111-119.

${ }^{15}$ A se vedea Jud. Cluj-Napoca, sentința penală nr. 220 din 3 martie 2011, disponibilă la adresa www.rolii.ro. Pentru cauze similare, a se vedea Jud. Cluj-Napoca, sentința penală nr. 188 din 1 martie 2011, definitivă, disponibilă la adresa www.rolii.ro; Jud. Cluj-Napoca, sentința penală nr. 636 din 19 mai 2011, definitivă, disponibilă la adresa www.rolii.ro; Jud. Cluj-Napoca, sentința penală nr. 760 din 9 iunie 2011, disponibilă la adresa www.rolii.ro.

${ }^{16}$ A se vedea Jud. Cluj-Napoca, sentința penală nr. 478 din 7 mai 2010, disponibilă la adresa www.rolii.ro.

17 A se vedea C.A. Cluj, secția penală și de minori, decizia nr. 820 din 8 octombrie 2014, definitivă, disponibilă la adresa www.rolii.ro; C.A. Cluj, secția penală și de minori, decizia nr. 1722 din 27 octombrie 2011, disponibilă la adresa www.rolii.ro; C.A. Cluj, secția penală și de minori, decizia nr. 1372 din 13 septembrie 2011, disponibilă la adresa $w w w$.rolii.ro.

18 A se vedea Trib. București, secția I penală, sentința penală nr. 125 din 30 ianuarie 2019, nedefinitivă, disponibilă la adresa www.rolii.ro. 
dintre care 7 infracțiuni având consecințe deosebit de grave, și 30 de infracțiuni unice de înșelăciune.

\section{Tulburarea de posesie}

Dintre cele 44 de persoane juridice cercetate penal în perioada $2007-2019$ pentru această infracțiune, (numai) trei au fost trimise în judecată.

Problema reținerii infracțiunii de tulburare de posesie potrivit art. 220 C.pen. din 1969 s-a ridicat într-o cauză în care s-a formulat plângere împotriva unei soluții de clasare. S-a reținut astfel că o societate care executase lucrări de reabilitare a unui drum național depozitase molozul provenit din respectivele lucrări pe terenul aparținând unei persoane, cu acordul primarului comunei în care se afla terenul. Apreciind că organele de urmărire penală nu au clarificat cine sunt făptuitorii în cauză, din probele administrate nereieșind cine anume a dat dispoziţie să fie depozitat molozul şi nici cine a realizat efectiv depozitarea molozului, instanţa a decis admiterea plângerii și trimiterea cauzei la procuror în vederea începerii urmăririi penale $^{19}$. Se cuvine menționat că, potrivit Codului penal în vigoare, infracțiunea ar fi fost incidentă doar dacă ar fi fost comisă prin violență, ameninţare sau desființarea ori strămutarea semnelor de hotar (art. 256 C.pen.).

$$
* * *
$$

La o primă vedere, s-ar părea că infracțiunile contra patrimoniului sunt cel mai des întâlnite în practica judiciară în ceea ce privește persoanele juridice, după cum se află în vârf și în cazul persoanelor fizice. Datele statistice ne arată că, deși există relativ multe urmăriri penale pentru astfel de fapte ${ }^{20}$, dosarele care ajung în fața instanțelor nu sunt atât de numeroase (prin comparație, ponderea dosarelor care au în vedere infracțiuni prevăzute în legi speciale este cu mult mai importantă). Iar dintre acestea, cele mai multe (peste 76\%) au în vedere infracțiuni de înșelăciune, comise în general în cadrul relaţiilor contractuale dintre societăţi (de regulă de dimensiune redusă), reprezentantul legal al persoanei juridice inculpate fiind de asemenea cercetat. Dosarele de acest gen ne pot oferi informații importante despre tipologia faptelor comise de entitățile colective în această materie și pot orienta măsurile de prevenire și control.

Materialul a fost publicat în revista online a Facultăţii de Drept, $\underline{\text { AUBD - Forum Juridic nr. }}$ $\underline{2 / 2020}$.

\footnotetext{
${ }^{19}$ A se vedea Jud. Gherla, sentința penală nr. 982 din 7 iunie 2013, disponibilă la adresa www.rolii.ro.

${ }^{20}$ Infracțiunile de înșelăciune sunt cele pentru care persoanele juridice sunt cel mai des cercetate, după cele de evaziune fiscală.
} 